\title{
Elliot Entis
}

Passion and perseverance have seen Elliot Entis down the long road of bringing transgenic salmon to market. His experiences 'swimming upstream' in animal biotech shows that endurance is key in bringing pioneering technologies to market.

Anyone who has spent time with Elliot Entis, CEO and cofounder of Aqua Bounty Technologies (ABT), has heard him say that he subscribes to the "pinball theory of life." That is, when the right people and the right ideas are bouncing around together, the combination eventually results in a high score.

Of course, it helps if there is a pinball wizard like Entis behind it all. His tenacity has earned him nicknames like 'cockroach' (impossible to kill) and he's been described as "willing to get up on his hind legs" to fight for what he believes in. The animal analogies fit Entis, who is guiding the first transgenic animal food product to market and recently led his BostonMassachusetts-based company to its successful $£ 20$ (\$37.6)-million Initial Public Offering (IPO) in March 2006.

ABT began with an idea about antifreeze proteins (AFPs) bouncing around Entis' head on an "idle Sunday afternoon, reading the New York Times" in 1991. Then running his father's wholesale seafood business, Entis saw the potential for preserving the flavor of frozen fish. After a few meetings with a group of scientists characterizing AFPs, namely Boris Rubinsky, Garth Fletcher and Choy Hew, he realized the much bigger potential for preserving human organs. And a new biotech company focused on using AFPs to preserve cells, tissues and organs called A/F Protein was born in 1992.

In an early meeting, a researcher offhandedly noted that they had used the promoter of the antifreeze gene found in ocean pout to turn on growth hormone in salmon year-round (salmon normally produce growth hormone only in the summer).

"I knew we were about to take an unexpected turn at that moment," says Entis, who's knowledge of aquaculture led him to refocus on this rapid-growing salmon. Aqua Bounty, the transgenic salmon portion of A/ F Protein, was spun off in 2000. And it became Aqua Bounty Technologies in 2003, reflecting a shift in the company to broader support of aquaculture through biotech products.

Entis counts that diversification as one of the wisest decisions he has made. "Up until 2000, we were only known for the transgenic salmon," he says. "Expanding to include products that focus on the health of aquaculture animals was a fulfillment of the original vision of the company, supporting the blue revolution of aquaculture. Commercially, it was a good move as well."

His investors agreed. ABT's pipeline now includes a hefty portion of shrimp therapeutics and diagnostics. ABT already has connections to the Latin American farmers, but Entis notes that the big prize will be Southeast Asia, which produces $75 \%$ of farmed shrimp.

"With his connections to the fish industry, Elliot understood the market opportunity for the shrimp products, which are more near-term, have lower regulatory hurdles and fill a huge unmet need in the developing world," says Rob Hopfner, vice president of Bay City Capital in San Francisco, the first venture capital firm to invest in ABT.

The move helped secure public trading on the alternative investment market (AiM), part of the London Stock Exchange. Choosing AiM let ABT avoid the onerous Sarbanes-Oxley reporting requirements in the US (See Lawrence article p731) and take advantage of fewer reporting deadlines, a faster due diligence process, with friendlier investors and smaller fund raisings than on Wall Street.

But the flagship product and Entis' raison d'etre for the past 14 years is the AquAdvantage salmon brood stock. These genetically modified (GM) salmon reach market size twice as fast as domestically farmed fish and convert feed to body mass slightly more efficiently. Production costs are thus $25-50 \%$ of traditional salmon farming.

Entis expects the salmon to be approved by the US Food and Drug Administration (FDA) later this year after a five-year review process. The lengthy review stems from a lack of policy guidance at the agency and an extra-cautious approach, both due to the pioneering nature of the product: a GM animal meant for consumption that swims in the ocean.

Those qualities have placed Entis squarely in the spotlight for attacks from anti-GM critics and for applause from the animal biotech industry. He admits his blood pressure soars when people shun any technology applied to food production. And though he has enemies within some groups, his determined promotion of the technology has won over many skeptics.

Early on, "Entis was vocally and vigorously defending his productthere's no fault there for a CEO_-but he was not always doing it scientifically," says William Muir, a population geneticist at Purdue University in West Lafayette, Indiana. A one-time critic of GM salmon and now a collaborator on risk assessment of the product, Muir credits Entis with

"He managed to sell
his dream very well
to over 150 investors
before going public,"
Rob Hopfner, Bay
City Capital.

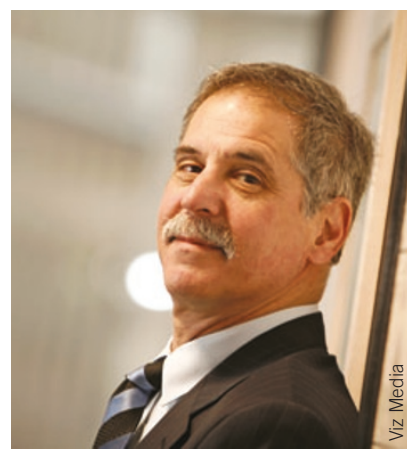

learning from the mistakes of agricultural biotech failures. "The biggest thing he did to help his cause was to announce the company's plan from the beginning-showing the public that the company is above board," says Muir.

Entis also has a talent for talk, communicating with investors, scientists, the general public and critics equally well. "He's not reactionary during emotional arguments," notes Kurt Klimpel, ABT's chief scientific officer, based in San Diego. "Instead, he will listen to a group's arguments and rationally go through them. Nine times out of ten, the argument is defused."

Entis' diplomatic tongue may be leftover from his political science training at Harvard and Berkeley. Add to that his passionate belief that GM salmon are a critical contribution to the world's food supply, and it becomes a winning combination for holding investor interest. The difficulties in raising funding in animal biotech separate these companies dramatically from their human healthcare counterparts.

"He managed to sell his dream very well to over 150 investors before going public," notes Hopfner of Bay City Capital. Some of those investors he kept interested for ten years or more as the fish crept toward approval. Now that approval seems near, those investors may reap a huge opportunity as the seafood industry shifts from fishing to aquaculture.

Kendal Powell, Boulder, Colorado 